\title{
МЕДІАКУЛЬТУРА
}

Visn. Lviv. Univ., Ser. Zhurn. 2019: 45; 323-334 • DOI: http://dx.doi.org/10.30970/vjo.2019.45.10015

УДК 007:304:070

\section{ЖУРНАЛІСТСЬКА ПРАВДА І ПОСТПРАВДА В КОНТЕКСТІ ГІБРИДНОЇ ВІЙНИ РОСІЙСЬКОЇ ФЕДЕРАЦІЇ ПРОТИ УКРАЇНИ}

\author{
Василь Лизанчук \\ Львівський національний університет імені Івана Франка, \\ вул. Генерала Чупринки, 49, 79044, Львів, Україна \\ e-mail:kafradioiteleb@ukr.net \\ https://orcid.org/0000-0001-6995-0360
}

Розглянуто терміни «правда» $\mathrm{i}$ «постправда», розкрито особливості журналістської творчості в умовах гібридної війни Російської Федерації проти України. Наголошено, що гібридна агресія є головною загрозою національній безпеці України. Проаналізовано типові компоненти гібридної війни. Показано, що дискурс гібридної війни є новітньою формою протистояння в сучасному безпековому довкіллі.

Ключові слова: журналістська професія, правда, постправда, гібридна агресія, інформаційно-психологічна війна, україноцентризм, національна свідомість.

Вступ. Нині історично-гуманітарний, інформаційно-духовний простір є надзвичайно важливим полем битви національно свідомих українців за свою автентичність, самобутність, національно-громадянську ідентичність. Адже гібридна війна Російської Федерації є головною загрозою національній безпеці України. «Феномен гібридної війни має два асиметричні модулі існування - матеріальний (фізичний) і дискурсивний. У військовому (матеріальному) вимірі російсько-український конфлікт є локалізованим, охоплюючи частину території України, натомість дискурс цієї гібридної війни набув глобального масштабу» [11, с. 468]. В основі російської гібридної війни - руйнування підвалин, що зміцнюють мілітарну, економічну, морально-духовну силу держави, яку Кремль хоче підпорядкувати собі. «Критично важливим елементом гібридної війни, що її веде Москва, є інформаційна війна як всеосяжна та узгоджена державна кампанія впливу, призначена спрямувати публічні дискусії в заданому Кремлем напрямку, встановлювати контроль над політичними, соціальними й медіанаративами та спотворювати інформаційний контекст для того, щоби впливати на рішення міжнародних організацій та країн по всьому світу щодо Росії, надавати валідності аргументам Кремля та задовольняти інтереси правлячої російської клептократії» [13].

(C) Лизанчук B., 2019 
Особливість суспільно-політичної ситуації в нашій державі полягає в тому, що основою гібридної війни є політичний сепаратизм, інспірований Російською Федерацією, яка здійснює агресію проти України.

Постановка проблеми. У монографії «Світова гібридна війна: український фронт» слушно наголошено, що інформаційна складова російської агресії багато в чому виявилася успішною через низку системних проблем медіапростору в Україні. «На початок 2014 р. в Україні практично не було створено дієвої системи захисту національного медійного i, зокрема, телерадіоінформаційного простору, натомість спостерігалася надмірна олігархізація медіа. Що ж до Донецької і Луганської областей, то тут склалася специфічна модель медіаспоживання внаслідок орієнтації місцевих приватних телерадіоорганізацій і друкованих видань на російський медіапродукт і браку безперебійного та щільного транслювання національного телерадіомовлення у цифровому та аналоговому форматах» [11, с. 474-475].

Тривала інформаційно-психологічна війна Російської Федерації проти України, яка переросла в цинічну військову агресію, спонукає шукати нові форми і методи протидії потужній московській маніпулятивній пропаганді, бо «немає інтересів вищих за національні. Вони вершина, вищої від якої нема» [7, с. 110], - наголошував Левко Лук'яненко, який 27 років карався в концтаборах комуністичного тоталітарного режиму.

Аналіз останніх досліджень і публікацій. Історичні виклики, загрози для української соборності, ідентичності, проблеми національної безпеки, морально-професійні засади функціонування ЗМІ були і є у полі зору науковців, журналістів, громадсько-політичних діячів. Серед них О. Власюк, В. Горбулін, С. Грабовський, М. Житарюк, П. Жовніренко, С. Калакура, С. Кононенко, С. Кость, В. Лизанчук, I. Лосєв, О. Ляшенко, К. Смаглій та інші. Лауреат премії імені Джеймса Мейса, публіцист, луганчанин Валентин Торба наголошує, що одвічний український ворог плекав потужну систему маніпулятивної пропаганди віками. «І головне - сила пропаганди ворога не в тому, хто її створює і як, а в споживачі. Споживач пропаганди ворога багатовіковий «москаль», якому байдужа істина. У нього є лише комплекс меншовартості, який російські ЗМІ компенсують відповідними навіюваннями про «трєтій Рім», «вєлікость» і «нєделімость» [14]. Надто велика кількість росіян живе міфами, істина травмує їх. Тому легко піддаються маніпуляції свідомістю, яскравим свідченням морально-психологічної травми-деградації є підтримка агресивно-цинічної, злодійсько-підступної ідеології і політики В. Путіна та його брехливих поплічників.

Дискурс гібридної війни Російської Федерації проти України набув глобального масштабу, $є$ новітньою формою протистояння у сучасному безпековому довкіллі. «На тлі відсутності якісного, цікавого, рейтингового продукту, спрямованого на інтелектуальний і культурний розвиток: аналітичних програм, історичних фільмів, науково-пізнавальних передач, - все це й призводить до деградації аудиторії телебачення, а, в підсумку, й усього населення країни» [4]. Природне покликання журналістів допомогти кожному співгромадянинові вийти на шлях світла, «дати рішучу справедливу відсіч усій тій московській маячні, яка брудною гнилою рікою лине на наші береги» [10], - наголошує Юрій Мушкетик.

Мета статті. В контексті гібридної війни Російської Федерації проти України на засадах україноцентризму всебічно обгрунтувати, що Правда - головна гуманітарно-інформаційна зброя проти російської маніпулятивної пропаганди. 
Лизанчук $B$.

Виклад основного матеріалу. Ще в давньоукраїнській державі Русь Володимир Великий, Ярослав Мудрий, Володимир Мономах, митрополит Іларіон орієнтували юні покоління на самопізнання і пізнання Бога, світу, людини, мови, природи, народу, держави, культури, сповідування високих моральних ідеалів. У «Поученні» (назву цього твору також пишуть «Повчання», «Повчання Володимира Мономаха своїм дітям», «Повчання дітям») Володимир Мономах закликав «премудрих - слухати, старшим покорятися; з рівними і меншими приязнь мати; без лукавства розмовляти, багато розуміти; не хулити розмовою, не лютувати словом; помисел чистий мати, спонукати себе на добрі діла Господа ради» [9, с. 18-19].

Однак в умовах нинішньої військової агресії неототалітарної Росії проти України нав'язується постмодерна парадигма, де сама спроба розрізнення добра і зла трактується як щось «примітивне». За словами знаного французького мислителя Ф. Гваттарі, «все годиться, все прийнятно». Публіцист Сергій Грабовський, осмислюючи філософію постмодернізму, наголошує, що в сенсі власне етики та моралі культура постмодернізму відмовляється від унормування рамок будь-яких типів поведінки, грунтується на дискурсивному плюралізмі, на варіабельності раціональностей, що призводить до відкидання ціннісного пріоритету про істинне і хибне, прийнятне i неприйнятне, до ігнорування «моральних центрів» не тільки в нормативному, а й у ціннісному значенні. Цей аспект антиукраїнської ідеології і політики всебічно розкрито у підручнику «Інформаційна безпека України: теорія і практика» [6].

Сповідуючи постмодерний культурний контент, у якому сплелися радикально різні, але при цьому цілковито рівноправні світоглядні парадигми, ідеологи «русского мира» заповзято нав'язують постмодерні постулати в Росії, Україні та Свропі, тобто, сприймайте нашу правду, адже, мовляв, всі правди рівнозначні, рівноправні, прийнятні. Навіюють думку, що українська національна ідея суверенного державотворення - це релікт старої доби, нав'язаний ворожими силами проти централізованої російської держави. Мовляв, українська держава - це штучне утворення, це помилка історії, тому їі треба виправляти - повернути Україну у лоно російської імперії. Для цього, за світоглядною парадигмою постмодернізму, яку путінські російські рашисти переплели зі сталінською і гітлерівською антинародною ідеологією і політикою людиновбивства, «все годиться, все прийнятно» [2], щоби делегітимізувати Українську державу і владу. На думку кремлівських імперіалістів, це дасть змогу «возз'єднати розділений народ», тобто включити територію і населення України, чи принаймні велику їхню частину, до складу Росії.

Нинішня гібридна війна Російської Федерації своїм корінням сягає в часи Орди, Московського царства, Російської імперії, СРСР. Її мета незмінна: зовнішня експансія, придушення свободи, знищення національної сутності завойованих народів і перетворення їх на ординців, манкуртів, які задля аморальних інтересів Московії навіть віддають своє життя. Завдяки потужній дезінформації російському суспільству постійно нав'язують ідею, що увесь світ хоче знищити Росію. На другому місці ворогом Росії після США московські маніпулятори називають Україну. Вважаю, що теперішня російська проблема не в одному Путіні, а в ординській психіці моксельців - московитів - росіян . І ця цивілізаційна проблема, на думку голови Правління громадської організації «Центр Стратегічних Досліджень» Павла Жовніренка, розв'яжеться лише внаслідок глибокого трансформування Російської держави і суспільства на гуманістичних засадах [3]. 
Гібридність нинішньої війни Росії проти України і всіх попередніх війн полягає у віроломстві, тотальній брехні, тобто постправді.

Академічний «Словник української мови» дає таке тлумачення слова «правда»: 1) те, що відповідає дійсності; істина; 2) правдивість, правильність; 3) справедливість; порядок, який грунтується на справедливості, протилежне кривді [12, с. 497].

Залежно від інтерпретації реального факту, події, явища, яка неминуча під час творення новин, журналіст «може опинитися на позиції «своєї правди», «іншої правди», «чужої правди» і навіть «ворожої правди», - наголошував професор I. Л. Михайлин. - Журналіст може відображати дійсність на засадах точності й достовірності, а може, навпаки, підігнати дійсність під свою ідеологічну концепцію, яка йому здається, в силу тих чи інших причин, правильною; може, нарешті, просто замовчати соціально вагому, потрібну суспільству інформацію» [8, с. 80-82].

За версією Оксфордського словника під терміном «постправда» треба розуміти обставини, за яких об’єктивні чинники, виважений аналіз мають менший вплив на формування індивідуальної і громадської думки, ніж вплив на емоції та особисті почуття. При цьому правду, істину відсувають на другий план, на задвірки. Постправда відкриває простір, в якому маніпулюють міфами, недоброзичливими фантазіями. На такому емоційно-психологічному полі аудиторія вірить у постправду, тобто неправду, представлену моральним авторитетом Правди. Наприклад, запущений міф ще за Катерини II, що великороси, малороси і білоруси один народ. Цей міф повторює Путін: він, мовляв, воює не зі своїм народом, а 3 хунтою, нацистами, фашистами, які захопили владу і засіли в Києві.

Під час великої щорічної прес-конференції, яка відбулася 14 грудня 2017 року, президент Росії В. Путін заявив (цитую мовою оригіналу): «Славянский мир сложно развивался. Сама Россия складывалась сложно из многих славянских племен. В конце-концов образовалась Русь, частью которой, центром которой был Киев. В этом смысле наши исторические и духовные, и прочие корни дают мне право говорить, что в основе своей мы один народ».

Чи відчуваєте, розумієте, шановний читачу, глибину путінської маніпуляції історичними фактами, подіями, явищами?! Думаю, що той, хто не володіє справжньою, правдивою історією України і Росії, обсяг інформації якого грунтується на маніпулятивних постулатах історії ВКП(б) та історії СРСР, висловлювання Путіна сприймає як аксіому. Насправді В. Путін вдало використав методи маніпуляційної пропаганди: «великої брехні», інсинуацій та метод «40 на 60», які схарактеризував В. Гриджук.

Будь ласка, ще раз уважно прочитаймо, що і як сказав Путін, щоби у словесному химерному павутинні відрізнити правду від брехні. Освіченим людям відомо, що центром Руси був Київ. Путін також про це сказав, щоби засвідчити свою «обізнаність». Водночас освічена людина зазначила б, що Русь - це давньоукраїнська держава, яка за найновішими дослідженнями уже була відома на міжнародній арені у 838 році $[1 ; 15]$. Але навіщо про це важливе історичне явище знати Путіну та зазомбованим поціновувачам його зловісної імперської політики?! У них злочинні прагнення - відродити на штиках імперію зла СРСР і соціалістичний табір східноєвропейських країн.

Щоби створити у громадян Російської Федерації довіру до себе, Путін використовує маніпуляційний метод «40 на $60 »$. Тобто, подає 50-60\% правдивої інформа- 
ціï, а решта - суцільна дезінформація, припудрена брехня. Думаю: всі погоджуються, що слов'янський світ і Росія розвивалися досить складно. І тут же Путін проповідує брехливий постулат, що Росія складалася із багатьох слов'янських племен. Цю інсинуацію Путін прикриває фразою, що врешті-решт створилася Русь, центром якої був Київ. Та повернімося до цієї фрази: у ній є ще два слова «частью которой». Словами «частиною якої» Путін нав'язує думку, що Русь і Росія - це одне й те ж, а Київ, мовляв, був лише частиною Росії. Отже, така «освічена» людина як Путін та його засліплені брехнею радники-порадники не хочуть знати, що у IX-XIV століттях Росії ще на світі не було, а Московське царство почало називатися «Российским государством» після того, як в 1721 році Петро I вкрав назву давньоукраїнської держави Русь і приклеїв її до Московії.

Головною метою Путіна - методом «великої брехні» ще раз блискавично засліпити нинішніх моксельців=московитів=росіян президентським «геніальним відкриттям», мовляв, історичні, духовні та інші корені дають йому право говорити, що росіяни і українці - один народ. У такий спосіб маніпулятор Путін цинічно намагається примусити громадян Російської Федерації, європейських країн та національно несвідомих українців повірити в те, що в Україні громадянська війна. Її, мовляв, розв'язала нацистсько-фашистська хунта, яка засіла в Києві, а московські очільники зброєю захищають свій народ, винищуючи українських громадян.

Подивімося історичній Правді у вічі та відкиньмо у безодню позолочену московську брехню. $Є$ сотні досліджень авторитетних вчених і я, вибачте за нескромність, у багатьох публікаціях наголошував, але й нині у зв’язку з безсоромними маніпуляціями Путіна потрібно нагадати, що Володимир Великий хрестив не московитів=росіян, не Росію, бо їі на світі ще не було, а Русь, тобто русичів. У IX-XII ст. не існувало російського народу (великоросів). На заліських теренах (Залешанській землі) - нинішня територія північної Росії, жили угро-фінські племена (мурома, меря, весь, чудь, мещера, мокша, мордва, пермь, нарова, угра та ін.). Їх називали народом моксель. Ці племена, а також тюркські народності (торки, берендеї, ковуї, чорні клобуки, половці) стали основою розвитку й утворення московитів=великоросів, які були слов’янізовані та християнізовані після хрещення Руси.

На базі слов'янських племен (поляни, деревляни, кривичі, словени, сіверяни, дуліби, тиверці та ін.) утворилася Русь, а не Росія, як стверджує В. Путін, в історичному розвитку з них сформувався український народ. Під «Руською землею» або «Руссю» (давньоукраїнською державою) розуміли територію Середнього Подніпров'я, визначену містами Київ - Чернігів - Переяслав. Зарубіжні джерела стверджують, що тільки до цих земель і міст вживали термін «Русь». Ні Новгородська земля, ні Суздальська (як і решта приєднаних до Києва земель), Руссю не були. У першому Новгородському літописі можна прочитати про поїздки новгородців «у Русь» (тобто до Києва, Чернігова або Переяслава). Так само «в Русь» їздили із Ростова, Суздаля. Центром Руської держави була територія полян, поляни були Руссю. Отже, русини=руські=українці та моксельці=московити=росіяни не одного роду-племені, це різні етноси і немає у них історичних, духовних та інших спільних коренів, як про це говорив Путін. Так звану «спільну історію» жорстокістю вибудували московські=російські загарбники України.

Професор грецької філософії Євген Калюжний, який народився в Нормандії (Франція), наголосив, що Русь, тобто середньовічну Україну, також називали ла- 
тиною «Рутенія». Саме це підтвердили російські історики. Наприклад, П. Третьяков писав: «Східна європейська Держава почала формуватися на цьому місці за два століття до появи Рюриковичів у Києві. Ще довгий час, до XII-XIII століть, тільки ці землі називалися Руссю або землями руськими... Саме Київська держава та її передмістя, де жили поляни, була Руссю». М. Тихомиров зазначив: «Русь - це антична назва Київської держави, країни полян». Інші російські історики - М. Приселков та А. Массонов уточнили, що держава Русь розташовувалася між трьома містами Києвом, Черніговом та Переяславом Руським [5].

В X ст. в межиріччі Оки та Волги на основі консолідації фіно-угорських і тюркських племен утворилося Ростово-Суздальське князівство. Його політичними центрами були спочатку Ростов, від початку XII ст. - Суздаль, а з другої половини XII ст. - Володимир-на-Клязьмі. На Суздальщині виріс син Юрія Долгорукого Андрій, мамою якого була половчанка. Русь = Україна йому була чужою, він став запеклим ворогом Києва. У 1169 р. Андрій Боголюбський на чолі великої армії 11 північних князів захопив Київ і віддав місто на поталу своїй брутальній раті. Суздальці нищили русичів з особливою ненавистю і люттю. Це була вже не традиційна міжусобна боротьба, а міжетнічна війна. Після жорстокого руйнування Києва Русь почала занепадати. Київ втрачав своє значення як економічного й культурного центру Руських земель. Заволодівши у 1240 р. Києвом, Батий добивав давньоукраїнську державу Русь.

Володимир Білінський у трьох томах науково-історичного дослідження «Країна Моксель, або Московія» також аргументовано доказав, що українці і росіяни це два різних народи, розвіяв десятки міфів Російської імперії. Серед них і такий: Москва не була заснована 1147 р. Юрієм Долгоруковим. Вперше поселення Москви було зафіксовано лише у 1272 р. під час третього перепису населення у володіннях Золотої Орди. А вже тільки у 1277 р. Московія з'явилася як князівство з дозволу золотоординського суверена. I була вона звичайним улусом, який залишався підвладним династії Чингізидів. До речі, академік В. Покровський був дуже гордий з історії своїх москалів, він вихваляв їх вищість над Свропою, бо Москва (він блискуче це довів) у своїй політиці, організації і тенденціях є спадкоємицею Золотої Орди, улусу потужних монголів над Волгою.

Від середини XIII ст. Московське князівство набирає вагомості і, за згоди та активної підтримки татаромонгольських ханів, завойовувало сусідні землі. Починаючи від Івана I Калити для досягнення своєї мети московські князі вдавалися до брехні, лицемірства, хитрощів, наклепів, інтриг, дворушності, хабарництва, підкупів, шантажу, вигадок, підступності тощо. Постулат «мета виправдовує засоби» був звичайним, буденним принципом усіх наступних поколінь російських політиків. За нинішнього владоможця Путіна ця «мета» набула найвитонченіших, найпідступніших, найжорстокіших форм.

Наголошую, що роси, русини, руські, українці - це історичні етноніми одного народу, мовою якого є українська, яка відома ще з VII ст. Не було одного «древнерусского языка», як це нав’язують маніпулятори загальноросійської єдності. Справжніми спадкоємцями Руси=Київської Руси стала Галицько-Волинська Русь, а не протомосковське Владимиро-Суздальське князівство, не Московія=Росія. Потім були Запорозька Січ і Українська Гетьманська Держава, поки їх не знищили московські загарбники. 
Лизанчук $B$.

Отже, постправда - це та ж брехня, але в більших масштабах, підсилена найновішими технологіями. Нагадаю, московський режим вкладає щорічно декілька мільярдів доларів саме у брехню, щоби впливати на світові процеси у своїх імперських інтересах і водночас поставати перед світом доброчинцем. 3 цією метою потужно використовує такий метод ведення гібридної війни як інформаційно-психологічна маніпулятивна пропаганда.

Хіба не нас з вами, не на всіх громадян України і Росії спрямована цинічна брехня, що українці для росіян братній народ і в той же час вбивають цвіт української нації. Мовляв, росіяни дуже люблять українців, стурбовані, переживають, що в Україні соціально-економічні проблеми, тому «нужно помочь украинцам избрать нового президента ибо этот не годится». Кремлівська кліка всіма методами і способами втручається у виборчий процес, щоби гетьманську булаву захопив новітній Іван Брюховецький, який танцюватиме під мелодію московсько-рашистської балалайки. Нинішні президентські вибори та майбутні вибори до Верховної Ради України - це генеральна битва за Україну в російсько-українській війні.

Наголошую, що антиукраїнська інформаційно-психологічна інтервенція $є$ зовнішньою і внутрішньою. Тобто, в Україні - триває війна на двох фронтах: проти ворожого наступу і впливу Росії та її сателітів, і проти совкових, олігархічних та корумпованих, промосковських сил в Україні. Другим фронтом і є внутрішня агресія, носіями якої є творці багатьох передач на телеканалах «Інтер», «NewsOne», «112», «Україна», «ZIK», «1+1» та на інших комерційних телевізійних і радіоканалах. У них розкошують українофоби, московські прислужники Олена Бондаренко, Бойко, Вілкул, Мураєв, Ганна Герман, Новінський, Медведчук, Портнов, Рабінович, Добкін, Червоненко, Шуфрич та інші, які спекулюючи багатьма недоліками суспільно-політичного і соціально-економічного життя, своїми брехливими виступами допомагають російським агресорам завадити утвердженню духовно-національної соборності України. Кремль і промосковські блудники в Україні досі шаленіють від того, що відроджено автокефальну православну церкву України, отримано Томос, над святістю якого безпардонно глузував В. Зеленський.

Важливо також розуміти, що патріотом України робить не кров, а усвідомлення, що людина - частка своєї Батьківщини і від її моральності, духовності, честі залежить гідність, честь України. Той, хто губить на життєвій дорозі українські національні і загальнолюдські морально-духовні почуття, цінності рано чи пізно служить злу, космополітичним викрутасам, допомагає хитрому дияволу забалакувати сумління і під гаслами правди входити в душу, у якій улеслива усмішка перетворюється у злоякісну пухлину нігілізму, зловорожості до українства, до української землі. Така ситуація в нашому суспільстві, особливо в умовах російської гібридної війни проти України, надто небезпечна, бо постмодернізм, посттоталітаризм, постколоніалізм, постгуманізм породили постправду і постетику. Д-р Мирослав Татарин, богослов, професор Університету св. Сроніма (Канада) наголосив, що світ постправди відкрив поле, на якому маніпулюють міфами. На такому інформаційному полі населення вірить у неіснуючі загрози й недоведені факти, себто вірить у неправду, представлену таким авторитетом як «Правда». Сила маніпулятивної пропаганди, дезінформації, популізму, постправди така підступна і вагома, що її важко виправляти.

Постправду, тобто майстерно сконструйовану неправду, потужно використовують російські політики та 3MI, що дуже заплутує, і люди не те що не знаходять 
правду, а навпаки - різко відхиляються від правди, оскільки беруть до уваги цілковиту брехню (М. Маринович), яка, на жаль, пронизує українське суспільство, а також Свропу й Америку.

Працівники ЗМІ покликані сприяти формуванню доброчесних людей, які би на українській землі, і не тільки, сіяли добрі зерна національної гідності і людського взаєморозуміння. Для цього потрібні глибокі знання історії України у європейському і світовому контекстах, висока культура національної пам'яті. Однак багато журналістів і політиків, як не прикро, чітко не розуміє сутності постправди, справжнього масштабу російської імперської загрози не тільки Україні, а й Європі. Ще страшнішим $є$ те, що недруги безпардонно нав'язують тезу, що в Україні «немає свободи слова». Відомий художник і «світський лев» Сергій Поярков зазначив, що він особливих скарг на утиски свободи не чув від справді національно свідомих, глибоких і яскравих журналістів, натомість сірі і бездарні на скигленні щодо «свободи слова» процвітають. «С свобода слова в Україні - і це очевидний факт, однак ані гідної суспільної уваги у багатьох працівників мас-медіа не було і немає, - наголосив філософ Ігор Лосєв. - Є ще і специфічна група журналістів, які працюють на Кремль за його щедрі «пряники» (сумнозвісний Кирило Вишинський отримував по 53 тисячі євро не на рік, а на місяць!)». Такі журналісти хочуть легалізувати і зробити абсолютно безпечною свою антиукраїнську діяльність, яку вони і називають «свободою слова». «Подібна публіка спостерігається і у сфері політологів та експертів» (І. Лосєв). Якщо свобода слова антиукраїнського спрямування, то кому потрібна така свобода слова?

Соціально небезпечним у журналістиці Іван Франко вважав тип гіпокрита лукавої, брехливої людини. Нині таких журналістів називають «корисними ідіотами». Нав’язана дискусія про якесь протистояння між стандартами журналістської професії і патріотизмом - це від диявола з отруйною голкою. В Україні війна! Не громадянська, а російсько-українська. Справжній український журналіст поєднує громадянську, україноцентричну позицію і професійні стандарти. Аморально підпадати під фальшиві гасла, мовляв, не можна застосовувати «мову ненависті», а надавати слово опонентам, бо у них інша точка зору, інший погляд на ситуацію. I тоді буде справжня дискусія. Вибачте, це - повний абсурд, бо про що можна дискутувати iз загарбниками, або з такими блудниками як Мураєв, Бондаренко, Добкін, Бойко, Герман, Новінський, Червоненко, Влащенко, Вілкул, Шуфрич та багатьма іншими?

Постправдисти майстерно використовують стандарт журналістської діяльності «баланс думок і поглядів», щоби під час російсько-української війни заполонити інформаційний простір антиукраїнським контекстом. Таку ситуацію французький філософ Філіпп де Лара схарактеризував так: «П'ять хвилин для Гітлера, п'ять хвилин для єврея».

Журналістські стандарти - це не безликість, безкрилість, не нав'язування думки, що журналіст якась планетарна істота, безнаціональне створіння, що у нього немає Батьківщини, що він без роду-племені. Ні! Головні вимоги журналістських стандартів - професійна компетентність, подавати оперативну, ретельно перевірену (кілька джерел), правдиву інформацію, не брехати, не маніпулювати фактами, подіями, явищами, не змішувати поняття добра і зла. Бо в основі неправдивих новин $є$ «логіка змія».

Вважаю, що дискутувати можуть на телебаченні, радіо, у пресі лише ті, хто займає стратегічну мету розбудови духовної української України і під час дискусії 
уточнюється тактика досягнення позитивної державотворчої мети. Як можна надавати ефір і шпальти газет тим, хто підриває український національний фундамент?! Ми покликані рішуче відкинути фальшиве гасло «Дві країни - одна професія», яке підтримує голова Національної спілки журналістів України Сергій Томіленко. Така позиція сприяє позбавленню української журналістики національно-громадянської сутності, зіштовхує її у багно космополітизму, меншовартості, інертності, дисперсної комунікації.

Україноцентризм - це світоглядна, філософська, морально-ідеологічна, громадянська, духовно-національна позиція. I політики, і громадські діячі, і журналісти мають оцінювати факти, події, явища $з$ позицій інтересів української людини, української родини, українського суспільства, української соборної держави. Адже журналіст, який бреше, маніпулює фактами - недалеко від тієї особи, що вбиває. Бо він готує психолого-ідеологічне, політичне підгрунтя для агресії та вбивства.

Журналісти, науковці не мають морального права піддаватися маніпулятивним технологіям щодо терміну «мова ворожнечі», яку сповідують Дуня Міятович, Станко, Куликов, Томіленко та їхні однодумці. Хіба не зрозуміло, що промосковські бойовики, сепаратисти, кремлівські найманці - це не ополченці, не борці проти московських загарбників, а люті вороги незалежної, духовно соборної України.

Українські 3МІ покликані називати українських героїв - героями, подвиг захисників України - подвигом, сепаратистську зраду - зрадою, російську брехню брехнею, московський злочин - злочином, російську агресію - агресією, російських прислужників, за висловом Тараса Шевченка, - московською блекотою і гряззю.

Україноцентризм грунтується на концепції націоналізму, який $є$ філософією буття Нації, їі життя, розбудови, а шовінізм, фашизм, нацизм і московський рашизм, що увібрав у себе шовінізм, фашизм, нацизм і більшовизм - це філософія поневолення і гноблення інших націй. Націоналізм породжує подвижників і героїв, а шовінізм, фашизм, нацизм, рашизм - убивць, грабіжників, загарбників, яничарів, холуїв.

Папа Франциск у своєму Посланні з приводу 52-го Всесвітнього дня суспільних комунікацій закликав творити «журналістику миру», журналістику без лицемірності, таку, що не приймає неправду, галасливі заклики та гучні декларації, журналістику «виконану людьми для людей», журналістику як служіння, як «місію» Добротворення. Цей християнсько-гуманістичний заклик вважаю одним з дуже важливих підмурків стосовно розвитку журналістикознавчої науки і функціонування ЗМI.

Відомо, що інформація - товар. Але яка якість, який зміст цього товару, якою енергією він насичений? Доброчинною чи підступно зловорожою?! Це - надзвичайно важливо в умовах гібридної війни Росії проти України. Що продає журналіст - зловорожість, паніку, істерику, розпач, безвихідь, чи розповсюджує історичну і сучасну правду, конструктивно критикує, прогнозує, рекомендує оптимальний спосіб вирішення проблеми, навіює позитивні емоції, впевненість, оптимізм, переконання, що українці здатні захистити і розбудувати свою Державу. Правда є найрадикальнішою протиотрутою проти «вірусу обману».

Тому в основі виступів політиків, журналістського спілкування 3 читачами, глядачами, слухачами має бути моральна чесність, правдивість, а перед собою - всечесність, які черпаються тільки 3 колодязя національного, українськоцентричного духу. Це допоможе проводити чітку лінію між диявольською голкою зла і христи- 
янським добром. Адже «моральний нейтралітет» та «етична амбівалентність» є серйозною загрозою української журналістики (Мирослава Барчук). Про це свідчать результати загальнонаціонального дослідження, яке провели Фонд «Демократичні ініціативи» імені Ілька Кучеріва спільно із соціологічною службою Центру Разумкова наприкінці 2017 р. Найкращий баланс довіри (перевагу довіри над недовірою) мають волонтерські організації (+37\%), Збройні сили України (+37\%), Церква $(+25 \%)$, громадські організації $(+4 \%)$. Негативну оцінку мають засоби масової інформації України з покажчиком (-6\%). Чи можна українським журналістам повернути довіру, авторитет, позитивний вплив? Про деякі аспекти створення доброго імені журналістів мовилося вище. Тут пошлюся на думки експерта Наталії Іщенко, яка слушно наголосила, що треба просто бути чесними - перед собою та перед своєю аудиторією, треба працювати задля розвитку українського суспільства, а не маніпулювати ним заради політичних преференцій або матеріальної вигоди, треба не забувати про честь професії, а не ставати заробітчанами «чєго ізволітє».

Найоптимальніший спосіб розвивати власну здатність мислити самостійно, українськоцентрично - це всебічне поглиблення знань, щоби професійно розрізняти правду, істину і постправду, що $є$ найкращою «протиотрутою» від будь-яких російських маніпуляцій фактами, історичною правдою та підступів інших ворогів України. Не тільки журналісти, а й політики, службовці всіх рівнів, депутати, науковці мають знати правдиву історію Росії та України, щоби не потрапляти у капкан «русского міра».

Висновки. Гібридна війна Російської Федерації проти України спонукає по-новому, не традиційно організовувати роботу засобів масової інформації. Вони мають функціонувати на засадах гуманістичного україноцентризму, а не шовіністично-імперського москвоцентризму.

Нині, під час виборів Президента України, а надалі - Верховної Ради, дуже важливо, щоби кожний журналіст, політик, викладач, студент, кожний громадянин глибоко опановував історичну і сучасну правду, щоби не потонути в улесливій, медоточивій олжі постправди, а мислив, думав, діяв, на засадах україноцентризму, щоби знову не потрапити у московську неволю. Згадаймо імператив Декарта «Думаю, отже живу». Але цього замало. Невідкладно вчімося правильно думати, адже як наголошував Паскаль, «правильно думати це морально-етична норма». Навіть найкритичніше журналістське розслідування має бути насичене енергією українського державотворення, а не спрямоване на знищення незалежності України.

Переконаний, що в нинішніх умовах гібридної війни Російської Федерації проти України «правильне думання» - це україноцентричне мислення, це - українськоцентрична позиція, це - україноцентричні вчинки, це - україноцентричні дії, спрямовані на захист, розвиток, утвердження нашої духовно і матеріально багатої соборної української України.

\section{REFERENCES}

1. Бойко І. До питання про час заснування Української держави / І. Бойко // Вісник НТШ. 2017. Ч. 58. С. 37-40.

2. Грабовський С. Постмодерна доба, війна і журналістика / С. Грабовський // День. 2014. 17-18 жовт. 
3. Жовніренко П. Феномен Орди / П. Жовніренко //День. 2019. 19 лют.

4. Іщенко Н. Програмування українців. Чому нація деградує і як боротися з цим / Н. Іщенко // День. 2019. 7-8 берез.

5. Калюжний Є. Київська Русь - це не Росія / Є. Калюжний // Літературна Україна. 2015. 16 лип.

6. Лизанчук В. Інформаційна безпека України: теорія і практика: підручник / В. Лизанчук. Львів: ЛНУ імені Івана Франка, 2017. 728 с.

7. Лук'яненко Л. Сповідь у камері смертників / Л. Лук'яненко. К., 1991. 124 с.

8. Михайлин І. Л. Журналістика як всесвіт: Вибрані медіадослідження / І. Л. Михайлин. Х.: Прапор, 2008. 512 с.

9. Мономах В. Поучення / Володимир Мономах. Львів: «Фенікс», 2001. 37 с.

10. Мушкетик Ю. Це повинен знати кожен / Ю. Мушкетик // Слово Просвіти. 2017. 20-27 квіт.

11. Світова гібридна війна: український фронт: монографія / за заг. ред. В. П. Горбуліна. К.: НІСД, 2017. 496 с.

12. Словник української мови. В. 11 т. / АН УРСР. Ін-т мовознавства ім. О. О. Потебні. К.: Наукова думка, 1976. Т. 7.

13. Смаглій К. Putinverstehers* вражає провідні мізки світу / К. Смалій // День. 2018. 2-3 листоп.

14. Торба В. Наша зброя - правда / В. Торба // День. 2014. 14-15 листоп.

15. Щодра О. Коли і де виникла Русь: проблеми початкового етапу формування Української державности / О. Щодра. Вісник НТШ. 2017. Ч. 58. С. 31-36.

\footnotetext{
* Putinverstehers - німецький політичний неологізм (Путін + versteher), який буквально перекладається «розуміння Путіна», тобто «той, хто розуміє Путіна». Термін застосовують до політиків та експертів, які висловлюють співчуття В. Путіну, тобто, хто каже «так, але ви повинні розуміти позицію Путіна».
} 


\title{
JOURNALISTIC TRUTH AND POST-TRUTH IN THE CONTEXT OF THE HYBRID WAR OF THE RUSSIAN FEDERATION AGAINST UKRAINE
}

\author{
Vasyl Lyzanchuk \\ Ivan Franko National University of Lviv \\ General Churprynka Street 49, 79044, Lviv, Ukraine \\ e-mail: kafradioiteleb@ukr.net \\ https://orcid.org/0000-0001-6995-0360
}

Author determined the terms «true» and «post-truth». According to the Oxford Dictionary, the term «post-truth» relating to a situation in which people are more likely to accept an argument based on their emotions and beliefs, rather than one based on facts. In such an information field, the population believes in non-existent threats and unproven facts, that is, believes in a lie presented by such authority as «Truth».

In the context of the hybrid war of the Russian Federation against Ukraine, the peculiarities of journalistic creativity were considered. The author described the typical components of a hybrid war against Ukraine: creation of internal socio-political contradictions in Ukraine through manipulative propaganda with its powerful continuation in the informationpsychological warfare; creating social and economic problems through economic confrontation with the transition to an economic war and counteracting charitable connections of Ukraine with its near and far neighbors; support for national nihilism of Ukrainians, separatism and terrorism up to acts of state terrorism; assistance in the creation of irregular armed units and their equipment.

Anti-Ukrainian intervention is external and internal. That is, in Ukraine there is a war on two fronts: against enemy attack and influence of Russia and its satellites and against the Soviet, oligarchic, corrupt and pro-Moscow forces in Ukraine. The second front is internal aggression, carriers of which are the creators of many broadcasts on TV channels, for example, Inter, News One, 112, Ukraine, ZIK and other commercial, television and radio channels.

Ukrainian media should call Ukrainian heroes - as heroes, the feat of defenders of Ukraine - a feat, separatist betrayal - as betrayal, Russian aggression - aggression. Russia's hybrid war against Ukraine is a war of moral-spiritual, national values, ideological, humanistic landmarks. The current Russian aggression is the determining moment of historical truth.

Key words: truth, post-truth, Russian aggression, information-psychological warfare, manipulative propaganda. 